\title{
CADMIUM TOXICITY REVISITED: FOCUS ON OXIDATIVE STRESS INDUCTION AND INTERACTIONS WITH ZINC AND MAGNESIUM
}

\author{
Vesna MATOVIĆ, Aleksandra BUHA, Zorica BULAT, and Danijela ĐUKIĆ-ĆOSIĆ \\ Department of Toxicology “Akademik Danilo Soldatovic”, Faculty of Pharmacy, University of Belgrade, \\ Belgrade, Serbia
}

Received in September 2010

CrossChecked in October 201

Accepted in February 2011

\begin{abstract}
Discovered in late 1817, cadmium is currently one of the most important occupational and environmental pollutants. It is associated with renal, neurological, skeletal and other toxic effects, including reproductive toxicity, genotoxicity, and carcinogenicity. There is still much to find out about its mechanisms of action, biomarkers of critical effects, and ways to reduce health risks. At present, there is no clinically efficient agent to treat cadmium poisoning due to predominantly intracellular location of cadmium ions. This article gives a brief review of cadmium-induced oxidative stress and its interactions with essential elements zinc and magnesium as relevant mechanisms of cadmium toxicity. It draws on available literature data and our own results, which indicate that dietary supplementation of either essential element has beneficial effect under condition of cadmium exposure. We have also tackled the reasons why magnesium addition prevails over zinc and discussed the protective role of magnesium during cadmium exposure. These findings could help to solve the problem of prophylaxis and therapy of increased cadmium body burden.
\end{abstract}

KEY WORDS: carcinogenicity, chelation therapy, dietary supplementation, essential elements

Detailed historical information on cadmium (Cd) has recently been reviewed by Nordberg (1). A German chemist Friedrich Strohmeyer discovered this metal in 1817 . Forty years later, acute gastrointestinal and respiratory symptoms were observed in persons using cadmium carbonate powder as a polishing agent. Increased occupational exposure to Cd was observed after 1912, when the production of nickel-cadmium (Ni-Cd) batteries started in Sweden. Further investigations confirmed the toxic effects of $\mathrm{Cd}$ on the lungs, kidneys, and bones. Damage to the lungs in Cd-exposed workers was reported as early as the 1930s, while Nicaud observed osteomalacia and Friberg proteinuria and emphysema in the 1940s $(1,2)$.
However, it was Itai-itai (ouch-ouch) disease that demonstrated the dangerous dimensions of $\mathrm{Cd}$ as an environmental pollutant. It was an endemic bone disease characterised by fractures and severe pain related to exposure to $\mathrm{Cd}$ that occurred after World War II in Toyama Prefecture in Japan $(1,3)$. The clinical symptoms and signs of osteomalacia and osteoporosis, femoral pain, lumbago and skeleton deformations, renal tubular dysfunction, immune deficiencies, apathies, malabsorption, and anaemia were observed mostly in multiparous women living along the contaminated Jinzu River basin. Elevated levels of Cd were found in patients' urine. In 1968, the Japanese government acknowledged that the disease was as an environmental disease related to 
Cd-contaminated water released from a mine into the Jinzu River, which was used to irrigate rice fields. The disease was the result of several unfavourable factors: consumption of $\mathrm{Cd}$ contaminated water and rice, low dietary intake of proteins, and essential element deficiencies due to multiple pregnancies. High Cd exposure levels were associated with adverse effects on the skeleton through toxic effects on kidney, and also, as was confirmed later, by direct $\mathrm{Cd}$ effects on bone tissue. For the first time, Cd pollution was shown to have severe consequences on human health. Subsequently, interest in $\mathrm{Cd}$, initiated by Friberg's observations of renal damage in occupationally exposed workers, arrived on the scientific scene (2).

The discovery of a $\mathrm{Cd}$-containing protein from horse kidney by Margoshes and Vallee (4) in 1957 marked the beginning of research of this lowmolecular weight, cysteine-rich protein named metallothionein by Kägi and Vallee (5). Further studies confirmed the important role of metallothionein in the toxicokinetics and toxicodynamics of $\mathrm{Cd}$ and identified the kidney as one of the critical organs of Cd toxicity (6).

Cadmium is classified as a toxic element without any beneficial role in human physiology. Several studies have shown the role of $\mathrm{Cd}$ as an essential metal in ruminants (7). It was recently reported that some marine algae contain a form of the enzyme carboanhydrase with cadmium instead of zinc $(\mathrm{Zn})$ in their active sites (8).

Cadmium has also found its place in the rapidly expanding field of nanotechnology, which is therefore likely to become yet another source of its toxicity. Cadmium-containing nanoparticles, known as $\mathrm{CdSe}$ or CdTe-core quantum dots, have numerous biomedical applications, especially in the diagnosis of cancer, due to their unique optical and electrical properties. Despite their potential to revolutionise medical therapy, Cd-containing quantum dots are potentially toxic and their use presents substantial risk (9-12).

Over the last 50 years, the awareness and concern about $\mathrm{Cd}$ toxicity have resulted in a vast literature on this matter. Cadmium was called "the metal of the $20^{\text {th }}$ century". Future investigations will continue in order to further elucidate its mode of actions and their mechanism(s), identify biomarkers of critical effects, and to develop preventive and therapeutic strategies to decrease Cd body retention (e.g. 13).

This article gives a brief review of $\mathrm{Cd}$ research until now, including our own, with a focus on the current significance of cadmium and its modes of action through induction of oxidative stress and interactions with selected essential elements.

\section{OCCUPATIONAL AND ENVIRONMENTAL EXPOSURE TO CADMIUM}

Cadmium is ubiquitous environmental and occupational pollutant. Today it is mainly used in the manufacture of nickel-cadmium batteries, pigments, and plastic stabilizers, whereas applications in alloys, solders and electroplating show a decreasing trend. Both natural and anthropogenic activities significantly contribute to environmental quantities of Cd. Natural sources of Cd include volcanic activity, forest fires, and soil particles carried by wind. Anthropogenic sources are copper $(\mathrm{Cu})$ and nickel (Ni) smelting and fossil fuel combustion. Occupational exposure to $\mathrm{Cd}$ usually occurs in mines, in the production of batteries and pigments containing $\mathrm{Cd}$, in the production and processing of $\mathrm{Cd}$, its alloys, and compounds, and in recycling electronic waste. The leading producers of this metal, mostly for Ni-Cd batteries, are China, Japan, and Korea. The last few decades have seen a significant drop in the production and use of $\mathrm{Cd}$, especially in the United States and the European Union. However, Cd continues to be a major health problem, mostly because of its long half-life (15 to 20 years) and persistence in the environment and a variety of tissues (14-17).

Air and drinking water $\mathrm{Cd}$ levels are not alarming; they keep around $0.04 \mu \mathrm{g} \mathrm{m}^{-3}$ and below $1 \mu \mathrm{g} \mathrm{L}^{-1}$, respectively (16). Therefore, air $\mathrm{Cd}$ does not significantly contribute to the total dose of $\mathrm{Cd}$ absorbed by the body, except in people living near or working in metal industries. Exposure of general population to $\mathrm{Cd}$ should be kept as low as possible. The EU has proposed that urinary $\mathrm{Cd}$ concentration should be below $0.66 \mu \mathrm{g} \mathrm{g}^{-1}$ of creatinine (16), which reflects the recent findings on the adverse effects of low-level Cd exposure. In a priority list of hazardous substances established by the US Comprehensive Environmental Response, Compensation, and Liability Act, Cd ranks seventh (17).

Cadmium does not degrade in the environment and can enter the food chain, which steadily increases the risk of human exposure. Cadmium is present in 
almost all kinds of food. Its concentration varies greatly with the type of food and the level of contamination. Human activities such as mining, waste incineration, fossil fuel combustion, and application of phosphate fertilisers and sewage sludge that contain $\mathrm{Cd}$ significantly contribute to the contamination of soils and consequently, cultivated plants. Wheat and rice, green leafy vegetables, and potatoes contain higher concentration than other foods from plants and account for more than $80 \%$ of Cd intake by food. Cadmium is also present in high concentrations in fish and sea food (molluscs and crustaceans) and also in offal products. Adults across Europe are exposed to $\mathrm{Cd}$ levels nearing the tolerable weekly intake (TWI) of $2.5 \mu \mathrm{g} \mathrm{kg}^{-1} \mathrm{~b}$. W. Cadmium TWI can also be exceeded in other subgroups such as children, vegetarians, and people who are occupationally exposed or live in polluted areas (16).

Beside food, cigarette smoke is the largest source of non-occupational exposure, because $\mathrm{Cd}$ tends to accumulate in tobacco leaves, and between $40 \%$ and $60 \%$ of inhaled $\mathrm{Cd}$ can enter blood circulation. Cadmium content in cigarettes may vary with cigarette brand, but the usual content per cigarette ranges between $1 \mu \mathrm{g}$ and $2 \mu \mathrm{g}$. While the average person absorbs around $1 \mu \mathrm{g}$ of $\mathrm{Cd}$ through food per day, smokers that smoke one pack of cigarettes per day can absorb additional $1 \mu \mathrm{g}$ to $3 \mu \mathrm{g}$ of $\mathrm{Cd}$ and thus heavy smokers have more than double the $\mathrm{Cd}$ body content $(14,15)$.

\section{CADMIUM TOXICITY AND CARCINOGENICITY}

The first reported human adverse health effect related to $\mathrm{Cd}$ was lung damage in exposed workers. Subsequent studies identified the kidney as the critical organ of $\mathrm{Cd}$ toxicity, although $\mathrm{Cd}$ also causes adverse effects on the liver, lungs, pancreas, bones, reproductive organs, placenta, and hematopoietic, nervous, and cardiovascular systems $(1,2)$. In a recent paper Bhattacharyya (18) gave an overview on data that confirm low-level Cd-induced osteotoxicity with decreased bone mineral density and calciotropic hormone levels. The Third US Health and Nutrition Examination Survey (NHANES III) (19), which included 8722 US citizens over the age of 40 , showed a significant association between $\mathrm{Cd}$ urine content and myocardial infarction. Findings of abnormal fasting glucose and diabetes suggest that $\mathrm{Cd}$ may cause prediabetes and diabetes mellitus in humans (20). Furthermore, $\mathrm{Cd}$ disrupts the endocrine function by binding to cellular steroid receptors and can have oestrogen-like and androgen-like activity (21). Occupational exposure to $\mathrm{Cd}$ has been associated with the lung, pancreas, prostate, breast, and kidney cancer $(22,23)$. The International Agency for Research on Cancer (IARC) and the US National Toxicology Program classified $\mathrm{Cd}$ as human carcinogen (category 1) $(24,25)$. As reviewed by Nawrot et al. (26) this classification is based on evidence of carcinogenicity collected in three lines, that is, epidemiological evidence, in vivo and in vitro studies. A relationship between $\mathrm{Cd}$ exposure and the occurrence of lung cancer was found in exposed workers who had a $20 \%$ higher risk of lung cancer than control workers. A prospective cohort study conducted in an area close to three zinc smelters showed an association between lung cancer incidence and $\mathrm{Cd}$ exposure; a twofold increase in 24-h urinary $\mathrm{Cd}$ excretion corresponded to a $70 \%$ greater risk of lung cancer. Furthermore, the pulmonary system is a target of Cd-associated carcinogenesis. Lastly, several studies provide evidence that cadmium may have carcinogen potential in vitro.

There is no definite evidence that $\mathrm{Cd}$ causes prostate cancer and only three out of 11 cohort studies have found a positive association (27). McElroy et al. (22) reported about high risk of breast cancer in women that correlated with the level of exposure. Correlations were also found between $\mathrm{Cd}$ levels and age-adjusted prostate and breast cancer incidence in Europe (28).

New methods such as differential gene and protein expression profiling in experimental animals exposed to Cd may help to better understand the mechanisms involved in Cd toxicity and carcinogenesis. This approach can help to develop molecular markers of $\mathrm{Cd}$ exposure, toxicity, and carcinogenesis that may be used in epidemiological studies for predicting the incidence of cancer in humans (29).

\section{MECHANISMS INVOLVED IN CADMIUM TOXICITY AND CARCINOGENICITY}

Over the last few decades, substantial efforts have been made to clarify the mechanisms of $\mathrm{Cd}$ toxicity. However, the precise mechanism(s) underlying 
particular toxicity remain unclear. The present knowledge, based primarily on in vivo and in vitro studies, suggests that $\mathrm{Cd}$ may cause numerous cytotoxic and metabolic effects that have not been sufficiently recognised, such as changes in enzyme activity, changes in proteins with sulphydryl groups (thioneins), induction of oxidative stress and apoptosis, changes in the structure and/or function of cell membranes, changes in DNA structure and altered gene expression, inhibition of ATP production in mitochondria, and interaction with $\mathrm{Zn}, \mathrm{Cu}, \mathrm{Ca}, \mathrm{Se}$, and other essential metals (30-32).

\section{Role of cadmium in oxidative stress induction}

The first evidence of increased lipid peroxidation (LPO) in mice hepatocytes co-cultured with $\mathrm{Cd}$ was given by Müller (33). The author described Cd-induced production of reactive oxygen species (ROS) through interaction with critical subcellular sites such as mitochondria, peroxisomes, and microsomes, that resulted in the generation of free radicals and LPO in subcellular membranous structures. Production of ROS has been reported later in a variety of cell culture systems, as well as in intact animals via all routes of exposure (34-37). We also found early signs of oxidative stress in the liver of mice exposed to a single oral Cd dose $\left(20 \mathrm{mg} \mathrm{kg}^{-1} \mathrm{~b}\right.$. w. in the form of $\left.\mathrm{CdCl}_{2}\right)$ through increased LPO level, expressed as malondialdehyde (MDA) after $6 \mathrm{~h}, 12 \mathrm{~h}$, and $24 \mathrm{~h}$ (38). Since $\mathrm{Cd}$ has no redox activity, it may enhance ROS production by suppressing free-radical scavengers such as glutathione (GSH) and by inhibiting detoxifying enzymes such as superoxide dismutase, catalase, and GSH peroxidase, and/or through other indirect mechanisms (39). The ways in which $\mathrm{Cd}$ can induce the formation of reactive species are summarised in Figure 1. Available data confirm that the formation of free radicals such as superoxide ion, hydrogen peroxide, and hydroxyl radicals involves depletion of GSH and changes in the activity of antioxidant enzymes (40). Our recent findings (41) showed that an acute oral $\mathrm{Cd}$ dose $\left(20 \mathrm{mg} \mathrm{Cd} \mathrm{kg}^{-1}\right.$ b. w.) significantly decreased the glutathione (GSH) content in mice liver $4 \mathrm{~h}, 6 \mathrm{~h}$, and $12 \mathrm{~h}$ after $\mathrm{Cd}$ administration and increased GSH in the kidney after $12 \mathrm{~h}, 24 \mathrm{~h}$, and $48 \mathrm{~h}$, but did not cause significant GSH changes in the testis. A twoweek oral Cd exposure (at dose of $10 \mathrm{mg} \mathrm{kg}^{-1} \mathrm{~b}$. w. of $\mathrm{Cd}$ given as aqueous solution of $\mathrm{CdCl}_{2}$ ) lowered renal levels and increased liver and testicular levels of GSH. These results, together with related findings of other authors, show that the effect of Cd on GSH tissue levels varies with animal species, dose, route, and duration of exposure. In general, acute exposure to metals decreases GSH levels due to the formation of metalGSH complexes and/or consumption by the GSHperoxidase under oxidative stress induced by metals.

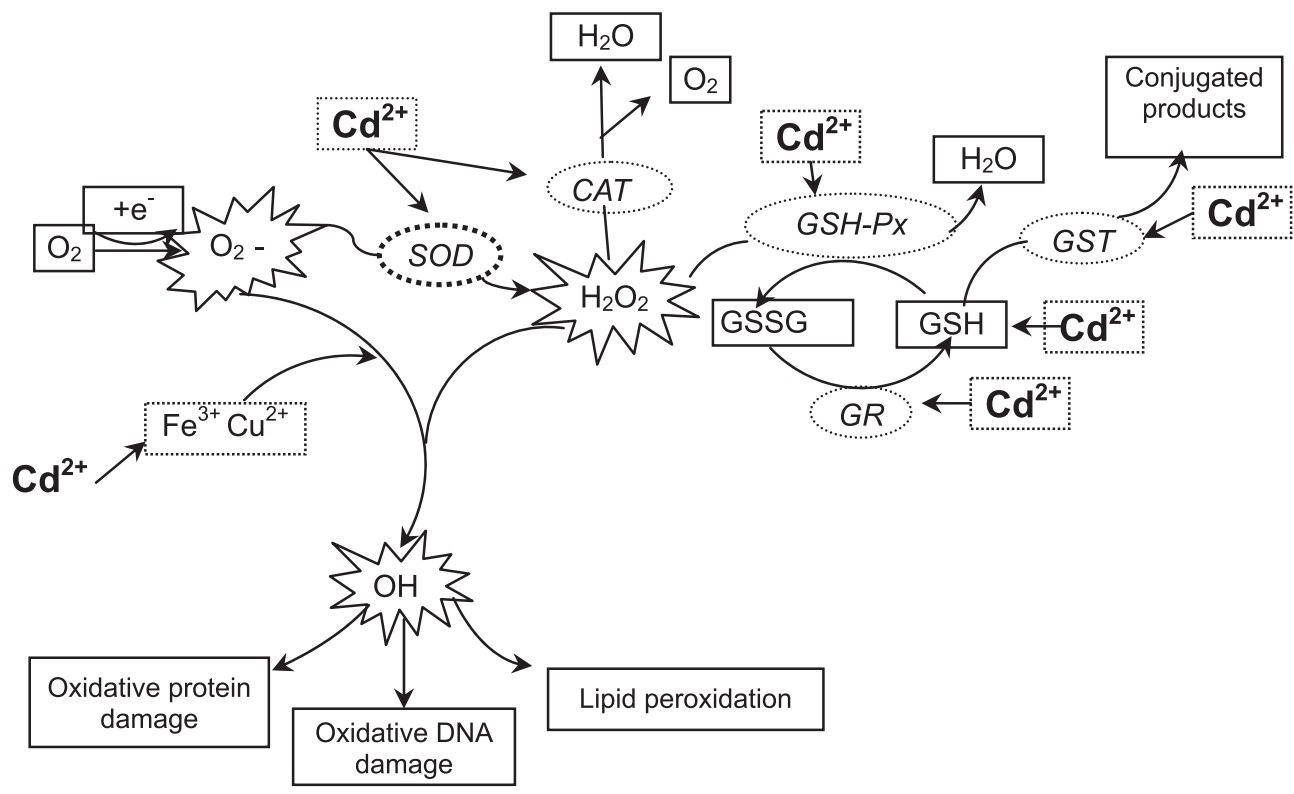

Figure 1 Pathways of Cd-induced generation of reactive oxygen species (adapted from ref. 39 by Danijela Đukić-Ćosić). Cadmium impairs enzyme activity of antioxidative defence system (superoxide dismutase, SOD; catalase, CAT; glutathione peroxidase, GSH-Px; glutathione-S-transferase, GST; gluathione reductase, GR) and of the non-enzymatic component glutathione, GSSG and GSH.

Cadmium also elevates the levels of Fenton metals $\left(\mathrm{Fe}^{3+}, \mathrm{Cu}^{2+}\right)$, which can break down hydrogen peroxide, $\mathrm{H}_{2} \mathrm{O}_{2}$ to a reactive hydroxyl radical, $\mathrm{OH}$. 
Casalino et al. (42) have proposed yet another mechanism of Cd-induced ROS production via iron $(\mathrm{Fe})$. Cadmium may displace $\mathrm{Fe}$ from various cytoplasmic and membrane proteins and consequently, increased concentration of ionic Fe stimulates ROS production in tissue. This is in agreement with our recent findings, which clearly show that acute and subacute $\mathrm{Cd}$ exposures change $\mathrm{Fe}$ content in the liver of mice (38). The results of this study also indicate that $\mathrm{Cd}$ affects MDA levels in a time-dependent manner. The observed MDA levels positively correlated with $\mathrm{Fe}$ in the liver. Oral exposure to a single dose of $\mathrm{Cd}\left(20 \mathrm{mg} \mathrm{kg}^{-1} \mathrm{~b}\right.$. w.) significantly increased LPO in the liver at $6 \mathrm{~h}, 12 \mathrm{~h}$, and $24 \mathrm{~h}$, and liver Fe after $4 \mathrm{~h}$ and $6 \mathrm{~h}$ up to $110 \%$ of control level. However, in mice orally exposed to $\mathrm{Cd}$ for two weeks (10 mg $\mathrm{kg}^{-1} \mathrm{~b}$. w. in form of $\mathrm{CdCl}_{2}$ in aqueous solution), we found liver Fe reduced by $80 \%$ and MDA by $74 \%$.

There are several other proposed mechanisms of $\mathrm{Cd}$-induced oxidative stress. One of these is Cdinduced inflammation in the liver. Kupffer cells are activated in response to $\mathrm{Cd}$ overload and produce inflammatory mediators such as IL- $1 \beta$, TNF- $\alpha$, IL- 6 , and IL-8, which in turn stimulate generation of free radicals in the liver (43). It has also been suggested that mitochondria are an important target of $\mathrm{Cd}$ toxicity (44).

When it comes to ROS production, the results of long-term exposure to low levels of $\mathrm{Cd}$ depend on experimental conditions such as dose, time intervals of oxidative stress evaluation, and animal species studied. It seems that ROS production has an important role in chronic $\mathrm{Cd}$ nephrotoxicity (45), immunotoxicity (46), and carcinogenesis (47). On the other hand, chronic exposure to $\mathrm{Cd}$ often elevates tissue GSH, without elevating tissue LPO levels $(37,45)$. This is confirmed by our own results (38), which showed initial increase in liver LPO and Fe levels $24 \mathrm{~h}$ after a single oral dose, which dropped after repeated $\mathrm{Cd}$ dosing. Prolonged $\mathrm{Cd}$ exposure through drinking water also caused a two-phase ROS response. At the beginning, ROS production rose, only to drop back to normal after eight weeks of exposure (48). It has been shown that ROS production does not play an essential role in chronic $\mathrm{Cd}$-induced malignant transformation in rat liver cells (49).

\section{Interactions between cadmium and essential elements}

It is well known that $\mathrm{Cd}$ interferes with the biokinetics and biological roles of many essential metals and metalloids such calcium $(\mathrm{Ca})$, magnesium $(\mathrm{Mg})$, sodium $(\mathrm{Na})$, potassium $(\mathrm{K}), \mathrm{Zn}, \mathrm{Cu}, \mathrm{Fe}$, manganese (Mn), selenium (Se), molybdenum (Mo), trivalent chromium $(\mathrm{Cr})$, cobalt $(\mathrm{Co})$, boron $(\mathrm{B})$, and other (30-32). However, the exact mechanisms involved in these interactions have not been entirely identified.

Cadmium and $\mathrm{Zn}$ interactions probably are one of the most recognised metal-metal interactions due to increasing environmental $\mathrm{Cd}$ exposure of the general population and concomitant widespread $\mathrm{Zn}$ deficiency in the world (14-17, 50). Since $\mathrm{Zn}$ is a co-factor in numerous enzymes and regulatory proteins, including the enzymes of DNA and RNA synthesis and repair, $\mathrm{Cd}$-induced disturbances in $\mathrm{Zn}$ homeostasis may have serious consequences on cell growth, development, and their functions. Because these two transitional metals are similar (both belong to the group IIb of the periodic table and form tetrahedral complexes) they compete for the same binding sites and/or ligands in biological systems.

A number of studies including our own (51-55) have shown that $\mathrm{Cd}$ disrupts $\mathrm{Zn}$ homeostasis. In turn, certain Cd-induced toxic effects, such as adverse reproductive and perinatal effects, may be amplified when $\mathrm{Zn}$ is depleted. Osman et al. (56) reported that multiparae, cigarette smokers in particular, run the highest risk of prenatal $\mathrm{Cd}$ toxic effects, which are associated with low $\mathrm{Zn}$ concentrations in serum, placenta, and cord blood. Exposure of rats to $\mathrm{Cd}$ lowered $\mathrm{Zn}$ levels in foetal tissues, accompanied by reduction of $\mathrm{Zn}$ metalloenzyme activities in both maternal and foetal tissues, which may be responsible for adverse reproductive outcomes (57). Our recent study on rabbits (58) has shown that prolonged oral exposure to $\mathrm{Cd}\left(10 \mathrm{mg} \mathrm{kg}^{-1} \mathrm{~b}\right.$. w. per day during four weeks) significantly lowered $\mathrm{Zn}$ in blood and nine organs.

Interactions between $\mathrm{Cd}$ and $\mathrm{Mg}$ have been less investigated than interactions with other essential metals, regardless of the fact that $\mathrm{Mg}$ has an outstanding physiological and biochemical role. Literature data and our own results suggest that $\mathrm{Cd}$ interferes with $\mathrm{Mg}$ absorption in the gastrointestinal tract and affects its homeostasis as well. We found altered $\mathrm{Mg}$ content in the organs of rabbits after prolonged $\mathrm{Cd}$ exposure $(58,59)$. Our new and yet unpublished investigations carried out on mice have confirmed these negative effects of $\mathrm{Cd}$ exposure (both by single oral dose to $20 \mathrm{mg} \mathrm{kg}^{-1} \mathrm{~b}$. w. and $10 \mathrm{mg}$ $\mathrm{kg}^{-1}$ b.w. per day during two weeks) on $\mathrm{Fe}, \mathrm{Zn}, \mathrm{Cu}$, and $\mathrm{Mg}$ tissue levels. 
More than thirty years ago, Smetana et al. (60) suggested that interaction between $\mathrm{Cd}$ and $\mathrm{Mg}$ might play a crucial role in the pathogenesis of idiopathic dilated cardiomyopathy. In the blood and urine of these patients $\mathrm{Cd}$ was increased, $\mathrm{Mg}$ decreased, whereas other metals $(\mathrm{Pb}, \mathrm{Zn}, \mathrm{Cu}$, and $\mathrm{Fe})$ were within reference range. While trying to determine the lowest $\mathrm{Cd}$ level in urine that is still associated with tubular dysfunction in Japanese women, Ezaki et al. (61) discovered that increased urine $\mathrm{Cd}$ levels were accompanied by increased excretion of $\mathrm{Mg}$.

In spite of significant improvements in occupational safety achieved in the last fifty years, recent literature data indicate that $\mathrm{Cd}$ exposure levels in certain occupational settings still remain as high as those reported in the factories of developed countries before the 1950s. In our recent study (62) of Ni-Cd factory workers in Serbia we determined blood and urine $\mathrm{Cd}$ levels to see if there were any $\mathrm{Cd}$-induced effects on the renal function and concentrations of $\mathrm{Zn}, \mathrm{Cu} \mathrm{Mg}$ and $\mathrm{Fe}$ in blood and urine. Although we expected them to be high, Cd levels kept within the range proposed by the World Health Organization (63) for occupationally exposed subjects $\left(10 \mu \mathrm{g} \mathrm{L}^{-1}\right.$ for blood and $10 \mu \mathrm{g} \mathrm{g}^{-1}$ of creatinine in urine). Altered values of $\beta_{2}$-microglobulin indicated disturbed renal function in only a few workers. We also found significantly lower concentrations of $\mathrm{Mg}$ in blood and of $\mathrm{Zn}$ in blood and urine.

Taken together, these results and similar reports in the field show that $\mathrm{Cd}$ interacts with several essential elements. In order to prevent adverse health effects, exposure to $\mathrm{Cd}$ should be as low as possible and exposed persons should include essential nutrient supplementation in everyday diet.

\section{Interactions between essential elements and cadmium}

\section{Zinc and cadmium interaction}

The antagonism between $\mathrm{Cd}$ and certain essential elements encouraged investigators to evaluate whether micronutrients such as $\mathrm{Zn}$ may influence $\mathrm{Cd}$ toxicity. Pařizek (64) published first data on beneficial effects of $\mathrm{Zn}$ supplementation against $\mathrm{Cd}$ toxicity as early as 1957. Later research of acute $\mathrm{Cd}$ exposure showed that $\mathrm{Zn}$ inhibited $\mathrm{Cd}$ transport along the terminal nephron segments in rats and vice versa (65). Jacquillet et al. (66) confirmed that $\mathrm{Zn}$ addition during $\mathrm{Cd}$ exposure prevented metal-induced changes in rat renal functions. Dietary $\mathrm{Zn}$ supplementation may also prevent $\mathrm{Cd}$-induced disorders in bone turnover. Brzoska et al. (67) reported that increased Zn intake during moderate or relatively high chronic $\mathrm{Cd}$ exposure can, at least partly, prevent disorders in bone metabolism.

Experimental data show that $\mathrm{Zn}$ can have an important impact on Cd-induced carcinogenesis as well. Waalkes et al. (68) suggested that excess $\mathrm{Zn}$ intake affected $\mathrm{Cd}$-induced prostate cancer by preventing testicular toxicity and maintaining testosterone production. $\mathrm{Hu}$ et al. (69) explored possible mechanisms responsible for $\mathrm{Cd}$-induced reproductive toxicity and prostate cancer in relation to $\mathrm{Zn}$. They monitored the expression of metallothionein genes, proto-oncogenes and tumour-suppressor gene p53 in rat prostate and testis, together with changes of testosterone level in serum. They showed that Cdinduced toxicity and the effects of $\mathrm{Zn}$ were complex. Although both $\mathrm{Cd}$ and $\mathrm{Zn}$ reduced testosterone, the initiation of prostate cancer is rather related to $\mathrm{Cd}$ induced altered gene expression.

In a recent investigation (70), we exposed rabbits to $\mathrm{Cd}$ (as $\mathrm{CdCl}_{2}$ in aqueous solution at oral dose of $10 \mathrm{mg} \mathrm{kg}^{-1} \mathrm{~b}$. w. of $\mathrm{Cd}$ per day) for four weeks and found that concomitant oral supplementation with $\mathrm{Zn}$ (as $\mathrm{ZnSO}_{4}$ in aqueous solution at dose of $20 \mathrm{mg} \mathrm{kg}^{-1}$ b. w. of $\mathrm{Zn}$ per day, given $1 \mathrm{~h}$ following $\mathrm{Cd}$ administration) reduced concentrations of $\mathrm{Cd}$ in blood and kidney (by $60 \%$ ) and to a lesser extent in the spleen, brain, and bone, in comparison to rabbits exposed to $\mathrm{Cd}$ only. The decrease in the $\mathrm{Cd}$ levels in analysed tissues was most probably due to the interaction between $\mathrm{Zn}$ and $\mathrm{Cd}$ in the intestinal lumen, where higher $\mathrm{Zn}$ content lowered gastrointestinal absorption of $\mathrm{Cd}$. Cadmium uptake occurs predominantly through $\mathrm{Zn}$-associated co-transport, as both ions compete for common binding sites and for membrane carriers such as divalent metal transporter1 and luminal $\mathrm{Zn}$ transporter-1 (71). Our results (70) also showed that $\mathrm{Zn}$ decreased renal $\mathrm{Cd}$, but did not reduce hepatic $\mathrm{Cd}$, probably due to $\mathrm{Zn}$-induced synthesis of metallothionein in the liver, which caused $\mathrm{Cd}$ accumulation in the liver and delayed its redistribution to the kidney. Zinc-associated lower $\mathrm{Cd}$ levels in spleen may be owed to the fact that this organ is richly vascularised and these values actually reflect blood Cd levels. Lower Cd brain levels after excessive intake of $\mathrm{Zn}$ could be explained by the ability of $\mathrm{Zn}$ to induce metallothionein synthesis, and the Cdmetallothionein complex can hardly cross the bloodbrain barrier. Recent investigations of the probable 
protective mechanisms of $\mathrm{Zn}$ in $\mathrm{Cd}$-exposed rats showed increased $\mathrm{Cd}$ levels in the kidney and suggested other protective mechanism of $\mathrm{Zn}$ action than MT synthesis, such as direct antioxidant action of $\mathrm{Zn}$ and $\mathrm{Zn}$-improved activity of antioxidant enzymes (72).

\section{Magnesium and cadmium interaction}

Limited experimental data point to beneficial effects of $\mathrm{Mg}$ against $\mathrm{Cd}$ toxicity. Boujelben et al. (73) showed that $\mathrm{Mg}$ supplementation could reduce both organ $\mathrm{Cd}$ accumulation and Cd-related LPO. The authors found that parenteral $\mathrm{Mg}$ supplementation (in form of sulphate) was associated with a dosedependent reduction in Cd levels in rat kidney, liver, and testis and lowered Cd-induced LPO in the liver and kidney. In the testis, the protective effect of $\mathrm{Mg}$ was present only during the early phase of $\mathrm{Cd}$ exposure.

We investigated the effect of supplemental magnesium in mice exposed to $\mathrm{Cd}$ (74). While acute oral $\mathrm{Cd}$ exposure $\left(20 \mathrm{mg} \mathrm{kg}^{-1}\right.$ b. w.) resulted in a significant renal $\mathrm{Cd}$ increase, pretreatment with $\mathrm{Mg}$ (40 $\mathrm{mg} \mathrm{kg}^{-1} \mathrm{~b}$. w) efficiently lowered kidney Cd levels $4 \mathrm{~h}$ and $6 \mathrm{~h}$ after $\mathrm{Cd}$ exposure. Similarly, the $\mathrm{Cd}$ content in the kidney was also elevated following two-week Cd exposure (10 $\mathrm{mg} \mathrm{kg}^{-1} \mathrm{~b}$. w. per os), and the effect was diminished by about $30 \%$ in mice pretreated with $\mathrm{Mg}\left(20 \mathrm{mg} \mathrm{kg}^{-1} \mathrm{~b}\right.$. w. per day). These results provide evidence that $\mathrm{Mg}$ has the ability to protect the kidney from $\mathrm{Cd}$ accumulation and point to the beneficial effects of $\mathrm{Mg}$ supplementation against $\mathrm{Cd}$-altered renal $\mathrm{Cu}$ and $\mathrm{Zn}$ levels (74).

Our further investigation (41) showed that $\mathrm{Mg}$ pretreatment significantly lowered $\mathrm{Cd}$ content not only in the kidney $(\sim 30 \%)$, but also in the lungs (50\%), spleen $(\sim 30 \%)$, and testis $(\sim 30 \%)$, following twoweek $\mathrm{Cd}$ exposure.

Results of our investigation on rabbits (70) exposed orally to $\mathrm{Cd}$ (as aqueous solution of $\mathrm{CdCl}_{2}$ at dose of $10 \mathrm{mg} \mathrm{kg}^{-1} \mathrm{~b}$. w. per day) for four weeks also showed that concomitant $\mathrm{Mg}$ supplementation $\left(40 \mathrm{mg} \mathrm{kg}^{-1} \mathrm{~b}\right.$. w. as an aqueous solution of $\mathrm{Mg}\left(\mathrm{CH}_{2} \mathrm{COO}\right)_{2}$ per day given $1 \mathrm{~h}$ after $\mathrm{Cd}$ administration) had the beneficial effects against tissue accumulation of $\mathrm{Cd}$. Excessive intake of $\mathrm{Mg}$ reduced blood, kidney, spleen, and bone $\mathrm{Cd}$ levels for about $30 \%$ in respect to rabbits given only Cd. However, we did not observe any relevant changes in the lungs, heart, liver, pancreas, muscle, and brain. This suggests that $\mathrm{Mg}$ modifies $\mathrm{Cd}$ absorption in the gastrointestinal system by affecting the intercellular leak of $\mathrm{Cd}$ from intestinal lumen to portal blood and thus reduces peripheral blood $\mathrm{Cd}$. The effect of $\mathrm{Mg}$ supplementation on renal $\mathrm{Cd}$ retention could be explained by $\mathrm{Cd}-\mathrm{Mg}$ competition during reabsorption. Furthermore, increased $\mathrm{Mg}$ in the lumen of the distal nephron could disable $\mathrm{Cd}$ uptake by intercellular transport and promote $\mathrm{Cd}$ elimination via urine.

\section{THERAPY OF CADMIUM POISONING}

No effective therapy of Cd poisoning has yet been developed, and currently it only addresses the symptoms (14). The most common agents, which have been used against heavy metal poisoning since World War 2 are chelators, starting with British Anti-Lewisite (BAL). After the war, calcium disodium ethylenediaminetetraacetate ( $\mathrm{CaNa}_{2}$ EDTA), deferoxamine, and D-penicillamine were introduced in clinical practice (75). However, none of the available chelating drugs is effective against poisoning with $\mathrm{Cd}$ because it quickly enters the tissue and binds to metallothioneins $(14,75)$. Some chelating agents such as polyaminocarboxylic acids [e. g. $\mathrm{CaNa}_{2}$ EDTA, calcium trisodium diethylenetriaminepentaacetate ( $\mathrm{CaNa}{ }_{3} \mathrm{DTPA}$ ), and zinc trisodium diethylenetriaminepentaacetate $\left.\left(\mathrm{ZnNa}_{3} \mathrm{DTPA}\right)\right]$, carbodithioates, deferoxamine (DFO), $N$-acetylcysteine (NAC), and 2,3-dimercaptosuccinic acid and its esters have shown some effectiveness in experimental animals when applied very soon after $\mathrm{Cd}$ exposure (75).

Literature data indicate the protective role of $\mathrm{Zn}$ supplementation against $\mathrm{Cd}$ toxicity, possibly because it stimulates metallothionein synthesis and competes with Cd for enzyme-binding sites (14, 67, 76-78). In addition, some studies have shown favourable effects of pretreatment with other essential elements on $\mathrm{Cd}$ toxicity $(79,80)$. Supplementation with minerals has not yet been approved for clinical use, since it is still not clear whether it is effective in subjects with adequate essential element intake, or only in $\mathrm{Zn}$ - and/ or Ca-deficient individuals Similarly, the role of supplementation with antioxidants, such as vitamins $\mathrm{A}, \mathrm{C}$, or $\mathrm{E}$, has been investigated in experimental settings in order to find an effective way to counter Cd-induced oxidative stress in tissue (14).

In our recent study of Cd in exposed rabbits (81), we determined the effects of increased oral intake 
of $\mathrm{Zn}, \mathrm{Cu}$ or $\mathrm{Mg}$ on the kinetics of $\mathrm{Cd}$ in various tissues to assess whether treatment with one of these bioelements could be used in prophylaxis and/or therapy of $\mathrm{Cd}$ poisoning. Rabbits were administered $\mathrm{Cd}$ by gastric tube (as aqueous solution of $\mathrm{CdCl}_{2}$ at dose of $10 \mathrm{mg} \mathrm{kg}^{-1} \mathrm{~b}$. w. per day) for four weeks, and three groups were supplemented oral $\mathrm{Zn}, \mathrm{Cu}$, or $\mathrm{Mg}$ [as aqueous solutions at doses of $20 \mathrm{mg} \mathrm{kg}^{-1} \mathrm{~b}$. w. of $\mathrm{Zn}$ in the form of $\mathrm{ZnSO}_{4} ; 10 \mathrm{mg} \mathrm{kg}^{-1} \mathrm{~b}$. w. of $\mathrm{Cu}$ in the form of $\mathrm{CuSO}_{4}$; or $40 \mathrm{mg} \mathrm{kg}^{-1} \mathrm{~b}$. W. of $\mathrm{Mg}$ in the form of $\left.\mathrm{Mg}\left(\mathrm{CH}_{3} \mathrm{COO}\right)_{2}\right]$ one hour after $\mathrm{Cd}$ exposure. Concentrations of $\mathrm{Cd}$ and essential elements were determined in blood and urine samples collected at different time intervals during the experiment and in nine organs (brain, heart, lungs, kidney, liver, spleen, pancreas, skeletal muscle, and bone) dissected at the end of experiment. Zinc supplementation was associated with reduced blood $\mathrm{Cd}$ throughout the experiment. Significant decreases were also determined in the kidney, brain, spleen, and bone. Similarly, $\mathrm{Mg}$ supplementation significantly reduced $\mathrm{Cd}$ in blood, kidney, spleen, and bone, without any significant changes in urine $\mathrm{Cd}$. Contrary to $\mathrm{Zn}$ and $\mathrm{Mg}, \mathrm{Cu}$ supplementation did not reduce $\mathrm{Cd}$ levels in blood, heart, and liver. These results have confirmed the antagonism between $\mathrm{Cd}$ and $\mathrm{Mg}$ as well as between $\mathrm{Cd}$ and $\mathrm{Zn}$, which is similar to our findings on the antagonism between $\mathrm{Pb}$ and $\mathrm{Mg}$ in experimental rabbits (82-86).

The effects of either $\mathrm{Zn}$ or Mg supplementation on $\mathrm{Cd}$ concentration and distribution in various tissues show similar beneficial effects on $\mathrm{Cd}$ body burden reduction in exposed rabbits. Although we found that $\mathrm{Zn}$ more efficiently reduced $\mathrm{Cd}$ tissue levels, especially in the kidney, we propose $\mathrm{Mg}$ as a dietary supplement of choice for reduction of $\mathrm{Cd}$ body burden, as the addition of $\mathrm{Mg}$ did not disturb either $\mathrm{Zn}$ or $\mathrm{Cu}$ levels. In turn, excessive $\mathrm{Zn}$ intake in our studies reduced $\mathrm{Mg}$ levels in blood and most of the investigated organs and increased its elimination via urine (58). Magnesium has a wide therapeutic range, and therefore further investigations are needed to justify its efficiency as a therapeutic agent against toxic metals, $\mathrm{Cd}$ in particular.

\section{CONCLUDING REMARKS AND PROSPECTS}

Cadmium is an occupational and environmental pollutant whose toxicity was eagerly investigated during the last decades. The pervasive nature of $\mathrm{Cd}$ in the environment and in biological tissues may have serious consequences, especially with respect to the role of $\mathrm{Cd}$ as a human carcinogen. Although the toxic effects of $\mathrm{Cd}$ are well known, the specific mechanisms by which it produces its adverse effects have yet to be fully investigated. Cadmium can cause oxidative stress, which may lead to cytotoxic and carcinogenic effects in target organs, and deeper insight into these mechanisms can give proper explanations to protect exposed population groups. However, there are great differences between in vivo and in vitro effects of $\mathrm{Cd}$ that still need to be addressed in research.

Literature data show that $\mathrm{Cd}$ affects the homeostasis of essential metals at the cell level. This review has focused on results, including our own, showing interactions between $\mathrm{Cd}$ and bioelements $\mathrm{Mg}$ and $\mathrm{Zn}$. In general, exposure to $\mathrm{Cd}$ reduces the levels of essential elements, which may have adverse health effects. On the other hand, $\mathrm{Mg}$ or $\mathrm{Zn}$ supplementation has a beneficial role in reducing $\mathrm{Cd}$ body burden and could be used for prevention and/or therapy. Years of our investigations in the field have confirmed the advantage of $\mathrm{Mg}$ over $\mathrm{Zn}$ supplementation. New research should look deeper into these complex interactions, as they go far beyond mere metal substitutions and are mediated in part by redoxsensitive systems acting at the transcriptional and transductional levels. A clearer insight into cation transporters and their specificity, cation effects on cell membrane transport, intracellular stores of $\mathrm{Cd}$, and molecular regulation of homeostasis of essential metals might help to explain interactions between $\mathrm{Cd}$ and essential metals.

Future research should fill in the lacking information to be used for environmental and human risk assessment. This information might be obtained by developing novel biomarkers for early detection of Cd-induced toxicity in exposed populations, subgroups in particular. Analytical methods should be improved by the -omics biomarkers and sophisticated biomarkers that keep pace with new Cd-exposure scenarios, such as exposures to Cd-based nanoparticles.

\section{Acknowledgement}

This work was partly supported by the Ministry of Science and Environmental Protection, Republic of Serbia (project No. III 46009) 


\section{REFERENCES}

1. Nordberg NF. Historical perspectives on cadmium toxicology. Toxicol Appl Pharmacol 2009;238:192-200.

2. Friberg L. Proteinuria and kidney injury among workmen exposed to cadmium and nickel dust. J Ind Hyg Toxicol 1948;30:32-6.

3. Tcuchiya K. Causation of ouch-ouch disease (Itai-Itai Byõ) an introductory review. II. Epidemiology and evaluation. Keio J Med 1969;18:181-94.

4. Margoshes M, Vallee BL. A cadmium protein from equine kidney cortex. J Am Chem Soc 1957;79:4813-4.

5. Kagi JH, Valee BL. Metallothionein: a cadmium- and zinccontaining protein from equine renal cortex. J Biol Chem 1960;235:3460-5.

6. Sabolić I, Breljak D, Škarica M, Herak-Kramberger CM. Role of metallothionein in cadmium traffic and toxicity in kidneys and other mammalian organs. Biometals 2010;23(5 Special Issue):897-926.

7. Memiši N, Žujović M, Bogdanović V, Tomić Z, Petrović MP. The influence of presence of cadmium and arsenic in feedmeal on production and reproduction traits of goats. Biotechnol Anim Husbandry 2008; 24:39-47.

8. Lane TW, Saito MA, George GN, Pickering IJ, Prince RC, Morell FMM. Biochemistry: A cadmium enzyme from a marine diatom. Nature 2005;435:42.

9. Derfus AM, Chan WCW, Bhatia SN. Probing the cytotoxicity of semiconductor quantum dots. Nano Lett 2004;4:11-8.

10. Kirchner C, Liedl T, Kudera S, Pellegrino T, Muñoz Javier A, Gaub HE, Stölzle S, Fertig N, Parak WJ. Cytotoxicity of colloidal CdSe and $\mathrm{CdSe} / \mathrm{ZnS}$ nanoparticles. Nano Lett 2005;5:331-8.

11. Green M, Howman E. Semiconductor quantum dots and free radical induced DNA nicking. Chem Commun 2005;1: 121-3.

12. Smith AM, Duan h, Mohs AM, Nie S. Bioconjugated quantum dots for in vivo molecular and cellular imaging. Adv Drug Delivery Rev 2008;60:1226-40.

13. New insights into the mechanisms of cadmium toxicity Advances in cadmium research, Special issue. Toxicol Appl Pharmacol 2009; 238 (3): 191-326.

14. Agency for Toxic Substances and Disease Registry (ATSDR). Toxicological profile for cadmium. Atlanta (USA): ATSDR; 2008.

15. Lewis GP, Coughlin LL, Jusko WJ, Hartz S. Contribution of cigarette smoking to cadmium accumulation in man. Lancet 1972;299:291-2.

16. Nawrot TS, Staessen JA, Roels HA, Munters E, Cuypers A, Richart T, Ruttens A, Smeets K, Clijsters h, Vangronsveld J. Cadmium exposure in the population: from health risks to strategies of prevention. Biometals 2010;23:769-82.

17. Agency for Toxic Substances and Disease Registry (ATSDR). CERCLA Priority list of hazardous substances that will be the subject of toxicological profiles and support document. Atlanta (USA): ATSDR, U.S. Department of Health and Human Services; 2007.

18. Bhattacharyya MH. Cadmium osteotoxicity in experimental animals: Mechanisms and relationship to human exposures. Toxicol Appl Pharmacol 2009;238:258-65.

19. Everett CJ, Frithsen IL. Association of urinary cadmium and myocardial infarction. Environ Res 2008;106:284-6.
20. Edwards JR, Prozialeck WC. Cadmium, diabetes and chronic kidney disease. Toxicol Appl Pharmacol 2009;238:289-93.

21. Darbre PD. Metalloestrogens: An emerging class of inorganic xenoestrogens with potential to add to the estrogenic burden of the human breast. J Appl Toxicol 2006;26:191-7.

22. McElroy JA, Shafer MM, Trentham-Dietz A, Hampton JM, Newcomb PA. Cadmium exposure and breast cancer risk. J Natl Cancer Inst 2006;98:869-73.

23. Il'yasova D, Schwartz GG. Cadmium and renal cancer. Toxicol Appl Pharmacol 2005;207:179-86.

24. International Agency for Research on Cancer (IARC). Cadmium and cadmium compounds, In: IARC Monographs on the evaluation of carcinogenic risks to humans. Vol. 58 . Beryllium, cadmium, mercury, and exposures in the glass manufacturing industry. Lyon: IARC; 1993. p. 119-237.

25. NTP Report on Carcinogens Background Document for Cadmium, March 1999. NIEHS Contract No. NO1-ES-25346 [displayed 9 January 2011]. Available at http://ntp.niehs.nih. gov/files/Cadmium.pdf.

26. Nawrot TS, Van Hecke E, Thijs L, Richart T, Kuznetsova T, Jin Y, Vangronsveld J, Roels HA, Staessen JA. Cadmiumrelated mortality and long-term secular trends in the cadmium body burden of an environmentally exposed population. Environ Health Perspect 2008;116:1620-8.

27. Jin YH, Clark AB, Slebos RJ, Al-Refai h, Taylor JA, Kunkel TA, Resnick MA, Gordenin DA. Cadmium is a mutagen that acts by inhibiting mismatch repair. Nat Genet 2003;34: 326-9.

28. Pan J, Plant JA, Voulvoulis N, Oates CJ, Ihlenfeld C. Cadmium levels in Europe: implications for human health. Environ Geochem Health 2010;32:1-12.

29. Joseph P. Mechanisms of cadmium carcinogenesis. Toxicol Appl Pharmacol 2009;238:272-9.

30. Moulis J-M. Cellular mechanisms of cadmium toxicity related to the homeostasis of essential metals. Biometals 2010;23:877-96.

31. Matović V, Plamenac-Bulat Z, Djukić-Ćosić D, Soldatović D. Antagonism between cadmium and magnesium: a possible role of magnesium in therapy of cadmium intoxication. Magnesium Res 2010;23:19-26.

32. Lazarus M. Međudjelovanje kadmija i selenija u sisavaca. Arh Hig Rada Toksikol 2010; 61:357-69.

33. Müller L. Consequences of cadmium toxicity in rat hepatocytes: Mitochondrial dysfunction and lipid peroxidation. Toxicology 1986;40:285-95.

34. Hart BA, Lee CH, Shukla GS, Shukla A, Osier A, Eneman JD, Chiu JF. Characterization of cadmium-induced apoptosis in rat lung epithelial cells: evidence for the participation of oxidant stress. Toxicology 1999;133:43-58

35. Liu F, Jan KY. DNA damage in arsenite-and cadmium-treated bovine aortic endothelial cells. Free Radic Biol Med 2000;28:55-63.

36. Manca D, Richard AC, Tra HV, Chevalier G. Relation between lipid peroxidation and inflammation in the pulmonary toxicity of cadmium. Arch Toxicol 1994;68: 364-9.

37. Amara S, Abdelmelek H, Garrel C, Guiraud P, Douki T, Ravanat J-L, Favier A, Sakly M, Ben Rhouma K. Preventive effect of zinc against cadmium-induced oxidative stress in the rat testis. J Reprod Dev 2008;54:129-34.

38. Djukić-Ćosić D, Curčić-Jovanović M, Plamenac-Bulat Z, Ninković M, Maličević Z, Matović V. Relation between lipid 
peroxidation and iron concentration in mouse liver after acute and subacute cadmium intoxication. J Trace Elem Med Biol 2008;22:66-72.

39. Valko M, Morris H, Cronin MTD. Metals, toxicity and oxidative stress. Curr Med Chem 2005;12:1161-208.

40. Liu J, Qu W, Kadiiska MB. Role of oxidative stress in cadmium toxicity and carcinogenesis. Toxicol Appl Pharmacol 2009;238:209-14.

41. Djukić-Ćosić D, Ninković M, Maličević Ž, Matović V, Soldatović D. Effect of magnesium pretreatment on reduced gluthatione levels in tissues of mice exposed to acute and subacute cadmium intoxication: a time course study. Magnes Res 2007;20:177-86

42. Casalino E, Sblano C, Landriscina C. Enzyme activity alteration by cadmium administration to rats: the possibility of iron involvement in lipid peroxidation. Arch Biochem Biophys 1997;346:171-9.

43. Yamano T, DeCicco LA, Rikans LE. Attenuation of cadmiuminduced liver injury in senescent male fischer 344 rats: role of Kupffer cells and inflammatory cytokines. Toxicol Appl Pharmacol 2000;162:68-75.

44. Belyaeva EA, Dymkowska D, Wieckowski MR, Wojtczak L. Mitochondria as an important target in heavy metal toxicity in rat hepatoma AS-30D cells. Toxicol Appl Pharmacol 2008:231:34-42.

45. Shaikh ZA, Vu TT, Zaman K. Oxidative stress as a mechanism of chronic cadmium-induced hepatotoxicity and renal toxicity and protection by antioxidants. Toxicol Appl Pharmacol 1999;154:256-63.

46. Ramirez DC, Gimenez MS. Induction of redox changes, inducible nitric oxide synthase and cyclooxygenase- 2 by chronic cadmium exposure in mouse peritoneal macrophages Toxicol Lett 2003;145:121-32.

47. Waisberg M, Joseph P, Hale B, Beyersmann D. Molecular and cellular mechanisms of cadmium carcinogenesis Toxicology 2003;192:95-117.

48. Thijssen S, Cuypers A, Maringwa J, Smeets K, Horemans N, Lambrichts I, Van Kerkhove E. Low cadmium exposure triggers a biphasic oxidative stress response in mice kidneys. Toxicology 2007;236:29-41.

49. Qu W, Diwan BA, Reece JM, Bortner CD, Pi J, Liu J, Waalkes MP. Cadmium-induced malignant transformation in rat liver cells: Role of aberrant oncogene expression and minimal role of oxidative stress. Int J Cancer 2005;114:346-55.

50. Wuehler SE, Peerson JM, Brown KH. Use of national food balance data to estimate the adequacy of zinc in national food supplies: Methodology and regional estimates. Public Health Nutr 2005;8:812-9

51. Task Group on Metal Interactions. Factors influencing metabolism and toxicity of metals: a consensus report. Environ Health Perspect 1978;25:3-41.

52. Plamenac Z, Matović V, Vujanović D, Soldatović D. Zinc content in rabbits submitted to prolonged cadmium intoxication. In: Kovatsis AV, Tsoukali-Papadopoulou h, editors. Aspects on Forensis Toxicology. Greece: ThessalonikiTecnika Studio; 1995. p. 31-5.

53. Brzóska MM, Moniuszko-Jakoniuk J. Interactions between cadmium and zinc in the organism. Food Chem Toxicol 2001;39:967-80.

54. Ishitobi h, Watanabe C. Effects of low-dose perinatal cadmium exposure on tissue zinc and copper concentrations in neonatal mice and on the reproductive development of female offspring. Toxicol Lett 2005;159:38-46.
55. Martelli A, Rousselet E, Dycke C, Bouron A, Moulis JM. Cadmium toxicity in animal cells by interference with essential metals. Biochimie 2006;88:1807-14.

56. Osman K, Akesson A, Berglund M, Bremme K, Schütz A, Ask K, Vahter M. Toxic and essential elements in placentas of Swedish women. Clin Biochem 2000;33:131-8.

57. Sorell TL, Graziano JH. Effect of oral cadmium exposure during pregnancy on maternal and fetal zinc metabolism in the rat. Toxicol Appl Pharmacol 1990;102:537-45.

58. Plamenac Bulat Z. Interakcije kadmijuma i bioelemenata cinka, bakra i magnezijuma kod ljudi i kunića izloženih kadmijumu [Interactions of cadmium and bioelements zinc, copper and magnesium in humans and rabbits exposed to cadmium, in Serbian]. [PhD thesis]. Belgrade: Faculty of Pharmacy, University of Belgrade; 2009.

59. Soldatović D, Matović V, Vujanović D, Stojanović Z. Contribution to interaction between magnesium and toxic metals: the effect of prolonged cadmium intoxication on magnesium metabolism in rabbits. Magnes Res 1998;11: 283-8.

60. Smetana RH, Glogar DH, Gemeiner M. Role of cadmium and magnesium in pathogenesis of idiopathic dilated cardiomyopathy. Am J Cardiol 1986;58:364-6.

61. Ezaki T, Tsukahara T, Moriguchi J, Furuki K, Fukui Y, Ukai H, Okamoto S, Sakurai H, Honda S, Ikeda M. Analysis for threshold levels of cadmium in urine that induce tubular dysfunction among women in non-polluted areas in Japan. Int Arch Occup Environ Health 2003;76:197-204.

62. Plamenac Bulat Z, Đukić-Ćosić D, Đokić M, Bulat P, Matović $\mathrm{V}$. Blood and urine cadmium and bioelements profile in nickel-cadmium battery workers in Serbia. Toxicol Ind Health 2009;25:129-35.

63. World Health Organization(WHO). Cadmium. Environmental Health Criteria No. 134. Geneva: WHO; 1992.

64. Pařizek J. The destructive effect of cadmium ion on testicular tissue and its prevention by zinc. J Endocrinol 1957;15: 56-63.

65. Barbier O, Jacquillet G, Taue M, Poujeol P, Cougnon M. Acute study of interaction among cadmium, calcium, and zinc transport along the rat nephron in vivo. Am J Physiol Renal Physiol 2004;287:F1067-75.

66. Jacquillet G, Barbier O, Cougnon M, Tauc M, Namorado MC, Martin D, Reyes JL, Poujeol P. Zinc protects renal function during cadmium intoxication in the rat. Am J Physiol Renal Physiol 2006;290:F127-37.

67. Brzóska MM, Rogalska J, Galazyn-Sidorczuk M, Jurczuk M, Roszczenko A, Kulikowska-Karpińska E, MoniuszkoJakoniuk J. Effect of zinc supplementation on bone metabolism in male rats chronically exposed to cadmium. Toxicology 2007;237:89-103.

68. Waalkes MP, Rehm S, Riggs CW, Bare RM, Devor DE, Poirier LA, Wenk ML, Henneman JR. Cadmium carcinogenesis in male wistar [Crl:(WI)BR] rats: Doseresponse analysis of effects of zinc on tumor induction in the prostate, in the testes, and at the injection site. Cancer Res 1989;49:4282-8.

69. Hu Y, Jin T, Zhou T, Pang B, Wang Y. Effects of zinc on gene expressions induced by cadmium in prostate and testes of rats. Biometals 2004; 17:571-2.

70. Bulat PZ, Djukić-Ćosić D, Maličević Ž, Bulat P, Matović V. Zinc or magnesium supplementation modulates $\mathrm{Cd}$ intoxication in blood, kidney, spleen, and bone of rabbits. Biol Trace Elem Res 2008;124:110-7. 
71. Bridges CC, Zalups RK. Molecular and ionic mimicry and the transport of toxic metals. Toxicol Appl Pharm 2005;204:274-308.

72. Jihen EH, Fatima H, Nouha A, Baati T, Imed M, Abdelhamid K. Cadmium retention increase: A probable key mechanism of the protective effect of zinc on cadmium-induced toxicity in the kidney. Toxicol Lett 2010; 196:104-9.

73. Boujelben M, Ghorbel F, Vincent C, Makni-Ayadi F, Guermazi F, Croute F, El-Feki A. Lipid peroxidation and HSP72/73 expression in rat following cadmium chloride administration: Interactions of magnesium supplementation. Exp Toxicol Pathol 2006;57:437-43.

74. Djukić-Ć́osić D, Ninković M, Maličević Z, Plamenac-Bulat Z, Matović V. Effect of supplemental magnesium on the kidney levels of cadmium, zinc, and copper of mice exposed to toxic levels of cadmium. Biol Trace Elem Res 2006;114: 281-92.

75. Blanuša M, Varnai VM, Piasek M, Kostial K. Chelators as antidotes of metal toxicity: therapeutic and experimental aspects. Curr Med Chem 2005;12:2771-94.

76. Brzóska MM, Galazyn-Sidorczuk M, Rogalska J, Roszczenko A, Jurczuk M, Majewska K, Moniuszko-Jakoniuk J. Beneficial effect of zinc supplementation on biomechanical properties of femoral distal end and femoral diaphysis of male rats chronically exposed to cadmium. Chem Biol Interact 2008;171:312-24.

77. Rogalska J, Brzóska MM, Roszczenko A, MoniuszkoJakoniuk J. Enhanced zinc consumption prevents cadmiuminduced alterations in lipid metabolism in male rats. Chem Biol Interact 2009;177:142-52.

78. Waalkes MP. Cadmium carcinogenesis. Mutat Res 2003;533:107-20.

79. Liu X, Jin T, Nodberg GF, Rännar S, Sjöström M, Zhou Y. A multivariate study of protective effects of $\mathrm{Zn}$ and $\mathrm{Cu}$ against nephrotoxicity induced by cadmium metallothionein in rats. Toxicol Appl Pharmacolacol 1992;114:239-45.

80. Turgut S, Enli Y, Emmungil G, Turgut G, Demir S, Kaptanoglu B, Genc O. Influence of cadmium and copper on tissue element levels of pregnant rats. Cent Eur J Med 2007;2:447-57.

81. Matović V, Plamenac-Bulat Z, Djukić-Ćosić D, Soldatović D. Zinc, copper or magnesium supplementation against cadmium toxicity: an experimental study. In: Blanc G, Moreu D, editors. Biometals: Molecular Structures, Binding Properties and Applications. $1^{\text {st }}$ ed. New York (NY): Nova Science Publisher; 2010. p. 1-31.

82. Matović V, Soldatović D, Vujanović D. Magnesium against lead: new approach to prophylaxis and therapy of chronic lead intoxication. In: Kotsaki-Kovatsi VP, Vafiadu AJ, editors. Aspects on Environmental Toxicology. Thessaloniki: Tecnika Studio; 1995. p. 78-82.

83. Soldatović D, Matović V, Vujanović D. Prophylactic effect of high magnesium intake in rabbits exposed to prolonged lead intoxication. Magnes Res 1993;6:145-8.

84. Soldatović D, Vujanović D, Matović V, Stojanović Z. Compared effects of high oral Mg supplements and of EDTA chelating agent on chronic lead intoxication in rabbits. Magnes Res 1997;10:127-33.

85. Soldatović D, Matović V. Influence of magnesium on the urinary lead excretion in rabbits submitted to chronic lead intoxication. In: Chhaparwal B, Durlach J, editors. Magnesium Research New Vistas. Indora: India; 1999. p. 125-31.

86. Soldatović D, Matović V, Vujanović D, Guiet-Bara A, Bara M, Durlach J. Metal pollutants and bioelements: retrospective of interactions between magnesium and toxic metals. Magnes Res 2002;15:67-72. 


\section{Sažetak}

\section{JOŠ O TOKSIČNOSTIKADMIJA - S POSEBNIM OSVRTOM NANASTANAK OKSIDACIJSKOGA STRESA I NA INTERAKCIJE S CINKOM I MAGNEZIJEM}

Iako je otkriven tek 1817. godine, kadmij je trenutačno jedan od najvažnijih onečišćivača životne i radne sredine. Štetno djeluje na bubrege, živčani sustav, kosti, reproduktivni sistem, a ima i genotoksične i karcinogene efekte. Nužna su dalja istraživanja vezana za mehanizme njegove toksičnosti, biomarkere efekata, kao i načine smanjenja rizika za zdravlje. Osim toga, do danas nije otkriven agens efikasan u terapiji trovanja kadmijem s obzirom na to da je kadmij intracelularni kation. U ovom radu dan je sažet pregled važnih mehanizama toksičnosti kadmija, kao što su nastanak oksidativnog stresa i interakcije s esencijalnim elementima, cinkom i magnezijem, na osnovi dostupnih literaturnih podataka, kao i naših ispitivanja koja upućuju na to da povećani unos navedenih esencijalnih elemenata pokazuje pozitivne efekte pri ekspoziciji kadmiju. Obrazložena je prednost suplementacije magnezijem pred suplementacijom cinkom i razmatrana preventivna uloga magnezija pri intoksikaciji kadmijem. Ovi su rezultati doprinos rješavanju problema profilakse i terapije trovanja kadmijem.

KLJUČNE RIJEČI: esencijalni elementi, karcinogenost, kelatna terapija, suplementacija

\section{CORRESPONDING AUTHOR:}

Professor Vesna Matović

Department of Toxicology "Akademik Danilo Soldatović"

Faculty of Pharmacy, University of Belgrade, Serbia

Vojvode Stepe 450, 11000 Belgrade, Serbia

E-mail:vevodi@pharmacy.bg.ac.rs 